\title{
Pengaruh Penggunaan Metode Discovery Learning dengan Teknik Buzz Group terhadap Keterampilan Berpikir Rasional Siswa
}

\author{
Syaiful Arif ${ }^{1 *}$, Imam Muchlash ${ }^{2}$ \\ ${ }^{1,2}$ Fakultas Tarbiyah dan Ilmu Keguruan, Institut Agama Islam Negeri (IAIN) Ponorogo \\ *Correspondence Address: syaiful@iaimponorogo.ac.id
}

\begin{abstract}
The buz: group discussion technique is a structured, effective, and requires students to be active in learning. This study is aimed at learning how the use of the discovery learning method with a buz: group technique has affected students' rational thinking skills. The research used experimental quasi methods for noninvasive control group design. Sample retrieval techniques using sample control techniques, classroom VIIII SMPN 1 Jenangan is taken in two classes the VIII C class (control) and the VIII D (experiment), the instrument of his research is a series of observations and tests to measure the reliability of rational thinking skills. The study uses only a post test as an instrument in data collection. Based on analysis of the independent test data analysis using minitab 16, the calculated t value of 8.68, the df value of 61 and the $P V$ alue of 0.000 , then the $P V$ alue $0.000<0.05$. Based on the results of the research and discussion, it can be stated that there is an influence of the use of discovery learning methods with the buzz group technique on students' rational thinking skills.
\end{abstract}

Keywords: discovery learning, bu₹z group, discussion, skills, rational thinking

\begin{abstract}
ABSTRAK
Teknik diskusi Buzz Group adalah teknik diskusi yang terstruktur, efektif, dan menuntut siswa untuk aktif dalam pembelajaran. Penelitian ini bertujuan untuk mengetahui pengaruh penggunaan metode discovery learning dengan teknik Buzz group terhadap keterampilan berpikir rasional siswa. Penelitian ini menggunakan metode Quasi Eksperimental jenis Nonequivalent Control Group Design. Teknik pengambilan sampel menggunakan teknik menentukan sampel, kelas VIII di SMPN 1 Jenangan diambil dua kelas yaitu kelas VIII C (kontrol) dan VIII D (eksperimen). Instrumen penelitiannya lembar observasi dan tes untuk mengukur kemammpuan keterampilan berpikir rasional. Penelitian ini hanya menggunakan post test sebagai instrumen dalam pengumpulan data. Berdasarkan hasil pembahasan analisis data uji independent $\mathrm{T}$ test dengan menggunakan minitab 16, nilai t hitung sebesar 8,68, nilai df sebesar 61 dan P Value sebesar 0,000, maka P Value 0,000< 0,05. Berdasarkan hasil penelitian dan pembahasan tersebut, maka dapat dinyatakan bahwa terdapat pengaruh penggunaan metode discovery learning dengan teknik buzz group terhadap keterampilan berpikir rasional siswa.
\end{abstract}

Kata kunci: discovery learning, buzz group, diskusi, keterampilan, berpikir rasional.

\section{PENDAHULUAN}

Pembelajaran IPA dalam kenyataannya masih banyak yang belum mencapai tujuan pembelajaran. Hal ini dikarenakan penggunaan metode dan teknik yang kurang tepat, dan juga disebabkan oleh minat belajar siswa yang masih rendah, banyak siswa yang beranggapan bahwa pelajaran IPA 
merupakan mata pelajaran yang paling sulit. Selain itu, peserta didik pasif bahkan ramai saat kegiatan pembelajaran. Pembelajaran IPA akan mencapai tujuan pembelajaran apabila siswa mampu berpikir, menganalisa, dan penalaran yang bagus terhadap materi pembelajaran, dalam menyelesaikan permasalahan serta menciptakan sebuah penemuan atau produk. Pembelajaran IPA sangat membutuhkan keterampilan berpikir untuk memudahkan siswa dalam memahami materi, dan memudahkan siswa dalam menyelesaikan permasalahan pada materi konsep IPA. Siswa harus dilatih untuk aktif dalam pembelajaran, mencari informasi sendiri dari berbagai sumber belajar, dan informasi tersebut dianalisis dan diolah kemudian hasil pemikirannya dideskripsikan. Sehingga kegiatan pembelajaran IPA diharapkan mampu melatih siswa untuk aktif, mandiri, dan meningkatkan minat belajar siswa.

Dalam Pembelajaran IPA keterampilan berpikir rasional siswa harus dikembangkan, keterampilan berpikir rasional siswa yang berdasarkan teori kontruktivisme (membangun diri sendiri secara mandiri) dari piaget. Menurut piaget pengetahuan yang dipahami dan yang dicerna siswa diolah dan dikembangkan dalam pikiran siswa itu sendiri. Pengetahuan real dengan pengetahuan logika tidak dapat dipindahkan dengan mudah dari pemikiran guru secara lengkap yang diberikan ke peserta didik, akan tetapi pemikiran tersebut juga harus dibangun sendiri oleh siswa. Salah satu metode tersebut adalah berinteraksi dengan lingkungan alam dan siswa mencari pengetahuan dari pengalaman mereka sendiri (Mujis, 2008; Puspitasari, 2016). Dengan demikian proses pembelajaran akan berhasil jika siswa mau terlibat aktif dalam pembelajaran dengan melibatkan semua inderanya, tidak hanya menerima materi dari guru saja sehingga menyebabkan siswa bosan dalam pembelajaran. Untuk itu seorang guru dituntut harus mampu menciptakan suasana belajar yang menyenangkan. Begitu juga yang diharapkan pada pembelajaran SMP kelas VIII (Astuti et al., 2012; Maghfiroh, 2013; Muchit, 2010; Rasyid, 2008).

Berdasarkan hasil pengamatan awal yang telah dilakukan di SMP Negeri 1 Jenangan Ponorogo 25 September 2019, menunjukan bahwa peran aktif pendidik menjadi hal terpenting. Karena siswa hanya mengandalkan guru sebagai pemeran utama atau sumber pengetahuan. Sebenarnya guru sudah melatih dan mengarahkan siswa untuk aktif dan berpikir kritis. Namun banyak siswa yang tidak mengikuti kegiatan pembelajaran dengan baik, siswa tidak aktif dan bahkan ramai saat guru menjelaskan materi ataupun saat kegiatan pembelajaran seperti diskusi. Sehingga situasi dan kondisi pembelajaran dikelas kurang aktif dan menarik, serta kurang adanya interaksi antara guru dengan murid dan murid dengan murid seperti kegiatan diskusi kelompok (Jamaris, 2014; Kumara, 2004; Yupita, 2013). Diskusi kelompok yang tidak efektif karena diskusi tidak terstruktur dalam pembagian tugas banyak siswa yang tidak mau ikut berpikir, mencari informasi, membahas suatu permasalahan bahkan tidak ikut mengerjakan dan pada akhirnya tugas tidak cepat selesai dan dan siswa tidak mengetahui hasil dari diskusi. Dan setelah presentasi kelompok jarang terjadi adanya tanggapan atau tanya jawab antar kelompok sehingga kegiatan diskusi kurang menarik dan tidak sesuai harapan. Kegiatan pembelajaran tersebut tidak terjadi pengembangan keterampilan berpikir rasional pada siswa, padahal dalam pembelajar-an IPA sangat membutuhkan keterampilan berpikir untuk memudahkan pemahaman materi dan menyelesaikan pemecahan masalah pada materi konsep IPA (Al-Tabany, 2017; Suryati, 2014; Taufiq \& Nurmaulia, 2015).

Berdasarkan hasil data pengamatan awal di SMP Negeri 1 Jenangan Ponorogo pada tanggal 25 September 2019. Penelitian ini menggunakan sampel satu kelas yaitu kelas VIII dengan jumlah 29 siswa dan menggunakan desain penelitian melalui tes uraian dan wawancara terhadap guru dan siswa. Tes uraian yang terdiri dari 5 soal dengan hasil indikator soal yaitu nilai rata-rata seluruh siswa pada indikator soal mengingat 58,33, menganalisa 65,74, mengklasifikasi 64,81, menggeneralisasi 65,74, dan menyimpul-kan 59,25. Dan presentase hasil belajar kemampuan berpikir rasional siswa dalam penelitian ini yaitu $41,67 \%$ siswa mempunyai keterampilan berpikir rasional yang cukup baik dan 58,33\% siswa tidak memenuhi kemampuan berpikir rasional. Rata-rata dari hasil tes seluruh siswa penilaian yaitu 70,62, dengan nilai KKM sebesar 80. Sehingga tingkat 
keterampilan berpikir rasional masih rendah, dan perlu dikembangkan dengan mengunakan metode atau teknik yang tepat (Muchlash, 2019).

Sedangkan dari hasil wawancara dan observasi di SMP Negeri 1 Jenangan, dalam pembelajaran pendidik sebenarnya menerapkan metode discovery learning dan Problem based learning sesuai dengan petunjuk dari kurikulum 2013 dan guru sudah mengarahkan siswa untuk aktif dan berpikir kritis namun siswa masih pasif dan minat dalam mempelajari pembelajaran masih rendah sehingga pembelajaran menjadi kurang menarik dan pembelajaran tidak meningkatkan keterampilan berpikir rasional siswa, serta hasil belajar siswa menjadi rendah. Kegiatan pembelajaran yang masih kurang mengembangkan interaksi antara guru dan siswa, dan antara siswa dengan siswa. Kedua metode tersebut sebenarnya dapat mengasah keterampilan berpikir rasional siswa, karena dalam kegiatan siswa diberi permasalahan seperti diskusi dan praktikum, kemudian siswa disuruh untuk untuk menemukan pengetahuan atau informasi sendiri dan menganalisis konsep tersebut. Sehingga siswa dituntut untuk berpikir kritis, logis dan analitis sesuai konsep yang dipelajari.

Dalam mengatasi permasalahan tersebut, penggunaan metode pembelajaran yang tepat yaitu metode discovery learning dengan teknik buzz group sebagai upaya meningkatkan keterampilan berpikir rasional siswa dan permasalahan-permasalahan tersebut. Metode dan teknik ini dapat mengarahkan siswa untuk berperan aktif dalam pembelajaran, sedangkan posisi guru sebagai fasilitator dalam membimbing siswa mempelajari materi, membantu siswa dalam menemukan pengetahuan, dan mengawasi siswa.

Menurut Roestiyah (2013) discovery learning adalah teknik mengajar yang melibatkan siswa, melalui kegiatan saling bertukar pendapat, membaca dan mencari informasi dari berbagai sumber, dan melakukan eksperimen. Siswa aktif menemukan informasi atau konsep sendiri dalam pembelajaran dengan arahan dari guru. Proses penemuan dapat dilakukan dengan berbagai cara salah satunya melakukan praktikum (Ekawati et al., 2017; Kusmaryono \& Setiawati, 2013; Lieung, 2019). Penggunaan metode Discovery Learning dan teknik diskusi buгz group sangatlah tepat untuk digunakan pada pembelajaran, karena metode ini berpusat pada kegiatan siswa yang berpikir rasional dan menggunakan lingkungan, buku, dan pengalaman sebagai sumber belajar lain. Model belajar tersebut dengan melakukan aktivitas yang dapat melatih keterampilan berpikir siswa melalui tahapan-tahapan yang sesuai dengan tingkat perkembangan siswa. Dengan siswa yang mandiri pembelajaran akan lebih bermakna karena siswa membangun konsep pengetahuan sendiri dari sumber lingkungan dan pengalaman siswa. Dalam diskusi kelompok seharusnya mengguna-kan teknik Buгz group agar kegiatan diskusi menjadi lebih efektif dan terciptanya pembelajaran yang aktif, kritis, dan berpikir rasional. Diskusi yang terstruktur karena ada pemimpin kelompok yang mengarahkan dan mengawasi teman diskusinya dan setiap anggota kelompok mempunyai tugas atau tanggung jawab untuk berpikir, mencari informasi, dan mengerjakan tugas. Sehingga tugas menjadi cepat selesai dan terciptanya interaksi antar siswa yang membahas suatu masalah, sehingga siswa menjadi fokus, tertarik dan paham materi yang dibahas.

Buг2 Group adalah satu kelompok besar atau siswa satu kelas yang dibagi menjadi beberapa kelompok kecil yang terdiri dari 3 sampai 6 orang. Buгz Group merupakan diskusi yang terstruktur karena setiap kelompok terdapat ketua, notulen, dan peserta diskusi, pembagian tugas dan tanggung jawab terhadap sertiap individu (Samad, 2011). Pemimpin kelompok yang bertugas mengarahkan dan mengawasi kinerja temannya, setiap anggota kelompok mempunyai tugas atau tanggung jawab untuk berpikir, mencari informasi, mengerjakan tugas dan diskusi. Sehingga tugas menjadi cepat selesai dan siswa paham materi yang dibahas.

Dalam diskusi teknik buzz group, posisi guru hanya berperan sebagai fasilitator yang bertugas untuk membimbing dan mengarahkan siswa dan mengkondisikan situasi diskusi kelompok agar berjalan lancar sesuai yang diharapkan dan tugas dari guru segera terselesaikan. Sehingga kegiatan diskusi tidak memakan waktu lama, dan kegiatan setelah diskusi terlaksana. Teknik buгzgroup dapat 
melatih siswa dalam bekerja sama dengan teman sekelompok dan melatih untuk berpikir atau menalar, dan mengolah informasi untuk menyelesaikan masalah. Siswa saling membantu menyelesaikan tugas dan saling bertukar pikiran sehingga pembelajaran menjadi lebih menyenangkan. Situasi kelas menjadi menarik dan siswa menjadi lebih aktif, dan kegiatan diskusi tersebut dapat mengembangkan kreativitas siswa secara kognitif, afektif, dan psikomotorik. Keunggulan penggunaan teknik buzz group dalam pembelajaran yaitu Kegiatan pembelajaran menjadi aktif, dan menyenangkan, dapat menumbuhkan kekompakan dalam kerjasama kelompok, memudahkan siswa untuk mengemukakan pendapat pada kegiatan diskusi, menumbuhkan sikap toleransi atau menghargai pendapat temannya, meningkatkan motivasi dan siswa menjadi lebih antusias dalam belajar, menumbuhkan sikap bertanggung jawab terhadap tugas yang harus dikerjakan dan menumbukan rasa percaya diri siswa dalam menyampaikan informasi dan tanya jawab(Azis et al., n.d).

Keterampilan berpikir rasional adalah kemampuan siswa dalam berpikir, menganalisa, dan penalaran terhadap materi pembelajaran, dalam menyelesaikan permasalahan siswa mencari informasi dari berbagai sumber belajar seperti buku, internet, dan pengalaman, kemudian siswa memahami dan mengolah informasi secara logis dan sesuai konsep. Pembelajaran IPA sangat membutuhkan keterampilan berpikir untuk memudahkan siswa dalam memahami materi, memudahkan siswa dalam menyelesaikan pemecahan masalah pada materi konsep IPA, dan dapat mengembangkan keterampilan siswa dalam menciptakan suatu penemuan atau produk. Untuk melatih keterampilan berpikir rasional guru mengarahkan siswa untuk mencari informasi sendiri dari bebagai sumber seperti membaca informasi tentang IPA dari buku maupun internet, kegiatan tersebut dapat melatih siswa untuk belajar mandiri dan meningkatkan minat belajar siswa (Haeruman et al., 2017; Retnosari et al., 2016; Rosidah, 2018).

Penggunaan metode discovery learning dengan teknik bur: group memberikan implikasi positif atau kontribusi untuk kegiatan pembelajaran IPA maupun mata pelajaran yang lainnya. Karena teknik pembelajaran tersebut siswa sangat terlibat aktif dalam pembelajaran, kegiatan siswa dalam mencari, menganalisis, mengolah informasi serta mengutarakan pemikirannya sendiri dan terciptanya interaksi saling bertukar pendapat. Teknik ini melatih dan meningkatkan aspek kognitif, afektif, dan psikomotorik siswa. Sehingga perpaduan discovery learning dengan teknik buz飞. group ini dapat memenuhi kebutuhan siswa dalam melaksanakan kegiatan pembelajaran dan berpengaruh terhadap hasil keterampilan berpikir rasional siswa. Berdasarkan permasalahan di atas, maka peneliti tertarik melakukan penelitian yang bertujuan untuk mengetahui pengaruh dari penggunaan metode discovery learning dengan teknik buz: group terhadap keterampilan berpikir rasional siswa.

\section{METODOLOGI}

Metode yang digunakan dalam penelitian ini adalah metode kuasi eksperimen (Quasi experimental). Tujuan menggunakan metode kuasi eksperimen yaitu untuk mengetahui ada tidaknya pengaruh dan seberapa besar pengaruh penggunaan metode Discovery Learning dan teknik burz group terhadap keterampilan berpikir rasional siswa. Penelitian ini eksperimen semu (quasiexperiment) penguji variabel bebas dan terikat yang diterapkan pada sampel kelompok kontrol dan kelompok eksperimen. Penelitian ini menggunakan desain post-test only control group.

Populasi dalam penelitian ini adalah peserta didik kelas VIII SMP Negeri 1 Jenangan sebanyak 6 kelas, dalam satu kelas berjumlah sekitar 29 siswa. Penelitian ini menggunakan teknik sampling atau teknik mengambil sampel untuk menentukan sampel yang digunakan dalam penelitian, Teknik yang digunakan teknik sampling non probability sampling dengan teknik purpose sampling atau teknik menentukan sampel (Sugiyono, 2014). Sampel adalah sebagian atau karakteristik yang mewakili populasi yang diteliti. Sampel penelitian ini menggunakan satu kelas dengan cara pengambilan sampel tidak secara acak, melainkan dari populasi yang berjumlah 6 kelas 
dan diambil dua kelas yaitu kelas VIII C dan VIII D, kelas VIII C sebagai kelas kontrol dengan menerapkan pembelajaran hanya menggunakan metode discovery learning. Sedangkan kelas VIII D sebagai kelas eksperimen dengan menerapkan metode discovery learning dan teknik buгz group dalam pembelajaran.

Instrumen yang digunakan pada penelitian ini adalah instrumet representasi analogi, yaitu suatu instrumen tes keterampilan berpikir rasional berupa soal tes berbentuk uraian, instrument tes penguasaan konsep fisika berupa soal tes penguasana konsep berbentuk uraian beralasan. Analisis uji coba instumen menggunakan uji validitas, reliabilitas, dan tingkat kesukaran soal menggunakan SPSS 16.0. Analisis data menggunakan uji Normalitas, uji Homogenitas menggunakan SPSS 16.0., dan uji Hipotesis penelitian ini diuji dengan menggunakan uji $\mathrm{T}$ dan analisis regresi linear sederhana menggunakan minitab 16.0. Aspek indikator soal yang digunakan yaitu Mengingat, menganalisis, mengklasifikasi, menggeneralisasi, dan menyimpulkan sebagaimana dalam Tabel 1 berikut.

Tabel 1. Aspek Indikator Soal

\begin{tabular}{|c|c|}
\hline Indikator & Deskripsi \\
\hline Mengingat & $\begin{array}{l}\text { Siswa menggunakan memori atau mengingat dilandasi } \\
\text { dengan menalar atau memikirkan suatu konsep. Ingatan } \\
\text { merupakan kemampuan berpikir untuk menyimpan } \\
\text { informasi dan mengutaran informasi kembali dalam } \\
\text { bentuk penjelasan. }\end{array}$ \\
\hline Menganalisis & $\begin{array}{l}\text { Kemampuan siswa dalam menjabarkan suatu } \\
\text { konsep/obyek dari hasil kegiatan mengklasifikasi, } \\
\text { membandingkan, dan meng-generalisasi. Menganalisis } \\
\text { data menghubungkan kriteria dari data-data untuk dibuat } \\
\text { generalisasi dan membandingkan kriteria yang diamati } \\
\text { dengan kriteria atau konsep lain yang sesuai. }\end{array}$ \\
\hline Mengklasifikasi & $\begin{array}{l}\text { Kemampuan siswa dalam mengelompokkkan atau } \\
\text { mengkategorikan obyek atau sebuah kasus berdasarkan } \\
\text { kriteria konsep tertentu. Kemampuan mengklasifikasi ini } \\
\text { dapat dilakukan dengan baik apabila kriteria suatu obek } \\
\text { dapat ditemukan dan memahami konsep yang terkait }\end{array}$ \\
\hline Menggeneralisasi & $\begin{array}{l}\text { Kemampuan siswa untuk dalam mengenali kembali } \\
\text { bahwa beberapa kasus adalah bagian dari konsep yang } \\
\text { lebih besar dan kemampuan menemukan konsep yang } \\
\text { terkait dapat menyelesaikan obyek yang diamati. Aspek } \\
\text { ini dapat dicapai bila mampu mengenali kriteria dari satu } \\
\text { atau beberapa obyek yang diamati mempunyai kesamaan } \\
\text { dan adanya hubungan dengan obyek-obyek lain yang } \\
\text { telah didefinisikan melalui konsep tertentu }\end{array}$ \\
\hline Menyimpulkan & $\begin{array}{l}\text { Hasil pokok dari analisis suatu masalah atau data-data } \\
\text { terpenting dari hasil pengamatan, dan keterpaduan semua } \\
\text { aspek kegiatan berpikir rasional. }\end{array}$ \\
\hline
\end{tabular}

Analisis yang digunakan dalam penelitian ini adalah analisis desktiptif. Analisis inferensial dilakukan dengan melakukan uji normalitas, uji homogenitas, dan pengujian hipotesis dengan uji T test. Analisis data menggunakan software IBM SPSS 16 dan minitab 16 dengan hipotesis:

Ho : Tidak ada pengaruh antara metode pembelajaran Discovery Learning dan teknik Buгz group terhadap keterampilan berpikir rasional siswa antara kelas eksperimen dan kontrol.

$H a$ : Ada pengaruh antara metode pembelajaran Discovery Learning dan teknik Buгzgroup terhadap keterampilan berpikir rasional siswa antara kelas eksperimen dan kontrol. 


\section{TEMUAN DAN PEMBAHASAN}

Sebelum instrumen digunakan untuk mengumpulkan data, instrumen tersebut diuji keakuratan dan ketepatannya menggunakan uji validitas dan uji reabilitas. Validitas dan reliabilitas diuji coba peneliti terhadap instrumen soal tes penelitian dengan uraian hasil sebagai berikut.

Uji validitas dilakukan peneliti bertujuan untuk mengukur kevalidan instrumen penelitian. Tingkat akurasi pengukuran yang menunjukan bahwa hasil data yang diperoleh valid atau kebenaran instrumen yang akan diberikan kepada sampel. Instrumen penelitian perangkat pembelajaran dan soal tes yang sudah divalidasi oleh 2 dosen ahli dan guru materi pelajaran IPA.. Setelah dinyatakan valid oleh validator dan dosen pembimbing, peneliti melakukan uji validitas di kelas IX C yang berjumlah 22 peserta didik.

Dalam menghitung data uji, peneliti menggunakan SPSS 16.0. Dengan kriteria yang digunakan untuk pengujian mengacu pada rumus $\mathrm{df}=\mathrm{n}-2$ dengan taraf signifikasi $5 \%$. df $=22$ $-2=20$, dengan nilai $\mathrm{r}$ tabel sebesar 0,3598 . Ketentuan hasil akhirnya apabila $\mathrm{r}$ hitung $>\mathrm{r}$ tabel maka item soal dinyatakan valid, sedangkan kalau $\mathrm{r}$ hitung $<\mathrm{r}$ tabel maka item soal dinyatakan tidak valid, dari uji 10 soal untuk mengukur keterampilan berpikir rasional menunjukkan $\mathrm{r}$ hitung $>\mathrm{r}$ table yang berarti 10 item soal tersebut dinyatakan valid.

Uji reliabilitas merupakan uji ketepatan hasil tes dalam menentukan reliabilitasnya butirbutir soal yang dijadikan sebagai post test. Uji reliabilitas dilakukan setelah soal-soal tes diuji validitas. Dalam penelitian uji reliabilitas menggunakan cronbach alpha untuk menentukan tingkat reliabilitas soal-soal tes keterampilan berpikir rasional. Soal dinyatakan reliabel apabila nilai alpha $\geq$ 0,6. Uji reliabilitas menggunakan SPSS 16.0, berikut hasil uji reliabilitas soal keterampilan berpikir rasional kelas IX C SMP Negeri 1 Jenangan Ponorogo:

Tabel 2. Hasil Uji Reliabilitas Soal Keterampilan Berpikir Rasional

\begin{tabular}{ccc}
\hline \multicolumn{3}{c}{ Reliability Statistics } \\
\hline $\begin{array}{c}\text { Cronbach's } \\
\text { Alpha }\end{array}$ & $\begin{array}{c}\text { Cronbach's Alpha Based on } \\
\text { Standardized Items }\end{array}$ & N of Items \\
\hline .844 & .845 & 10 \\
\hline
\end{tabular}

Berdasarkan hasil uji reliabel di atas dinyatakan bahwa soal-soal tes keterampilan berpikir rasional reliabel karena nilai cronbach alpha $0,845 \geq 0,6$. Total nilai cronbach alpha 0,845 dikategorikan uji reliabilitas sangat tinggi. Sehingga peneliti dapat menggunakan soal tes keterampilan berpikir rasional untuk post test di kelas VIII C (kelas kontrol) dan VIII D (kelas eksperimen).

Taraf kesukaran adalah tingkat kesulitan soal yang diujikan, kemampuan siswa dalam mengerjakan soal dengan benar atau bilangan yang menunjukan sukar atau mudahnya soal. Penentuan kriteria soal yang termasuk dalam kategori mudah atau sulit yang dilihat dari kesanggupan atau kemampuan siswa dalam menjawab soal tersebut. Analisis tingkat kesukaran soal menggunakan Microsoft Excel diperoleh hasil bahwa soal uraian berjumlah 10 butir, terdapat 5 soal termasuk kategori soal tingkat kesulitan sedang yaitu pada soal nomor 1, 2, 3, 4,dan 7 . Sedangkan soal nomor 5, 6, 8, 9, dan 10 kategori soal sukar.

Dalam analisis data peneliti menggunakan tiga uji yaitu uji normalitas, uji homogenitas,dan uji hipotesisi. Uji normalitas merupakan uji data yang bertujuan untuk mengetahui data dari sampel kelas dalam penelitian berasal dari populasi yang berdistribusi normal atau tidak. Data post-test keterampilan berpikir rasional diuji normalitas. Untuk menguji normalitas pada penelitian ini menggunakan uji kolmogrof smirnov pada SPSS 16.0 dengan taraf signifikan $5 \%$. 
Apabila nilai signifikan $>0,05$ data dinyatakan berdistribusi normal. Sedangkan jika nilai signifikan $<0,05$ maka data dinyatakan tidak tidak berdistribusi normal.

Uji normalitas data post test keterampilan berpikir rasional pada kelas kontrol dan kelas eksperimen berdistribusi normal atau tidak berdistribusi normal. Pengambilan data post test keterampilan berpikir rasional kelas eksperimen dilakukan di kelas VIII D dan pengambilan data post test keterampilan berpikir kelas kontrol rasional dilakukan di kelas VIII C. Soal tes berbentuk soal essay yang berjumlah 10 soal. Materi soal tentang materi sistem ekskresi manusia, soal mencakup 5 indikator keterampilan berpikir rasional. Indikator mengingat, menganalisis, mengklasfikasi, menggeneralisasi, dan menyimpulkan

Tabel 3. Hasil Uji Normalitas Post Test Keterampilan Berpikir Rasional Siswa Kelas Eksperimen dan Kelas Kontrol Menggunakan SPSS

\begin{tabular}{ccccc}
\hline & & \multicolumn{3}{c}{ Tests of Normality } \\
\hline & Kelas & \multicolumn{3}{c}{ Kolmogorov-Smirnov $^{\mathbf{a}}$} \\
\cline { 2 - 5 } Beterampilan & Statistic & df & ig. \\
\hline Pest-Tes & .112 & 2 & $200^{*}$ \\
& $\begin{array}{c}\text { Eksperimen } \\
\text { (DL \& Buzz } \\
\text { Group) }\end{array}$ & & & \\
\cline { 2 - 5 } & Post-Test & .152 & 1 & 067 \\
Kontrol (DL) & & & \\
\hline
\end{tabular}

\footnotetext{
a. Lilliefors Significance

Correction

*. This is a lower bound of the true significance.
}

Berdasarkan tabel di atas menunjukan bahwa hasil uji normalitas dengan menggunakan uji kolmogrof smirnov dan Saphiro Wilk menggunakan SPSS 16.00, hasil uji kolmogrof smirnov data post test menunjukan bahwa taraf signifikan dari hasil kelas eksperimen sebesar 0,200, sehingga taraf sig. lebih dari 0,05 . Sedangkan data post test uji kolmogrof smirnov taraf signifikan dari hasil kelas kontrol yaitu sebesar 0,067. Maka hasil dari uji kolmogrof smirnov di kelas kontrol dan eksperimen dinyatakan berdistribusi normal karena hasil nilai taraf signikan lebih besar dari nilai 0,05 ,

Keterampilan Berpikir Rasional

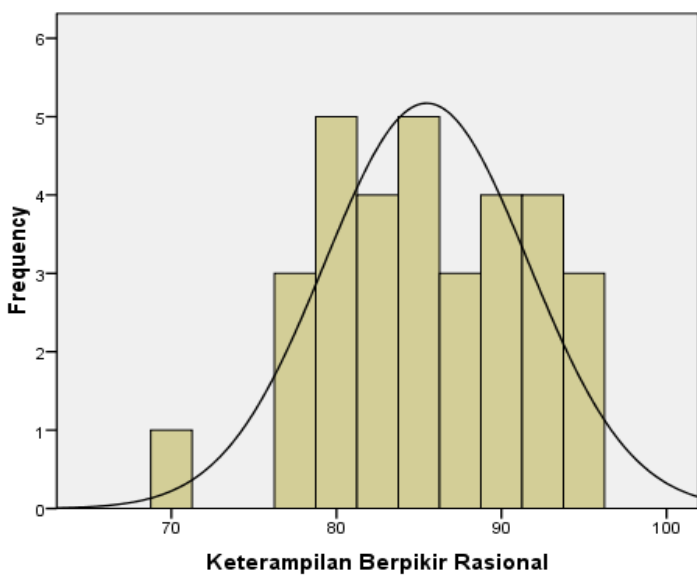

Mean $=85.47$
Std. Dev $=6.171$
$\mathrm{~N}=32$

Gambar 1. Grafik Data Post Test Keterampilan Berpikir Rasional Kelas Eksperimen

Berdasarkan grafik data post test keterampilan berpikir rasional kelas eksperimen di atas dinyatakan bahwa data berdistribusi normal karena data post test keterampilan berpikir rasional 
dari siswa kelas eksperimen yang berjumlah 32 siswa dengan nilai rata-rata 85,47 dan standar deviasi 6,171. Hal tersebut dapat disimpulkan bahwa data post test keterampilan berpikir rasional siswa dinyatakan berdistribusi normal. Pada perhitungan uji normalitas kolmogrof Smirnov dan Saphiro Wilk dinyatakan berdistribusi normal taraf signifikan lebih dari 0,05 dan juga dari grafik uji normalitas yang menunjukan data berdistribusi normal.

Keterampilan Berpikir Rasional

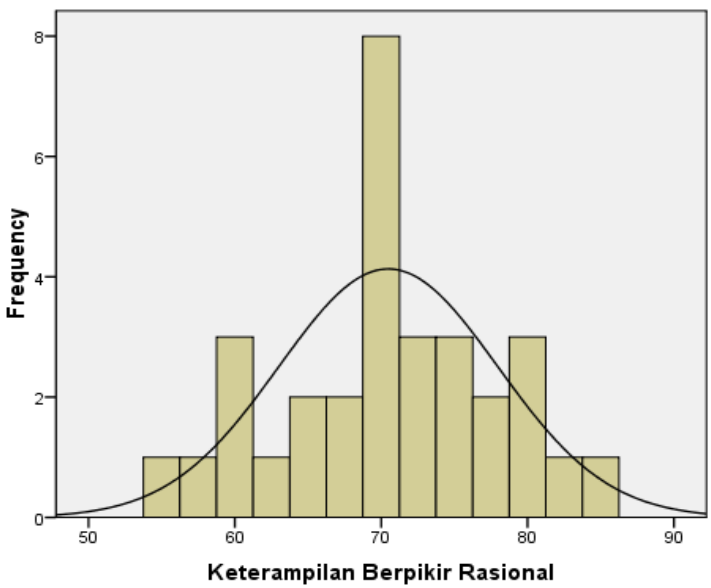
Mean $=70.48$
Std. Dev. $=7.484$
$N=31$

Gambar 2. Grafik Data Post Test Keterampilan Berpikir Rasional Kelas Kontrol

Berdasarkan grafik data post test keterampilan berpikir rasional kelas eksperimen di atas dinyatakan bahwa data berdistribusi normal karena data post test keterampilan berpikir rasional dari siswa kelas kontrol yang berjumlah 31 siswa dengan nilai rata-rata 70,48 dan standar deviasi 7,484. Hal tersebut dapat disimpulkan bahwa data post test keterampilan berpikir rasional siswa dinyatakan berdistribusi normal. Pada perhitungan uji normalitas kolmogrof Smirnov dan Saphiro Wilk dinyatakan berdistribusi normal taraf signifikan lebih dari 0,05 dan juga dari grafik uji normalitas yang menunjukan data berdistribusi normal.

Uji homogenitas bertujuan untuk mengetahui sampel dari penelitian mempunyai variansi yang sama, sehingga generalisasi dari hasil penelitan yang sama atau berbeda. Data yang diuji homogenitas yaitu data post test keteraampilan berpikir rasional. Uji homogenitas penelitian ini menggunakan uji levene. Apabila nilai signifikan > 0,05 data dinyatakan homogen. Sedangkan jika nilai signifikan $<0,05$ maka data dinyatakan tidak homogen. Untuk menguji homogenitas menggunakan pada SPSS 16.0 dengan nilai taraf signifikan 5\%.

Uji homogenitas post test keterampilan berpikir rasional siswa diujikan untuk mengetahui data hasil post test di kelas eksperimen dan kelas kontrol mempunyai data yang homogen (sama) atau heterogen (tidak sama). Pengambilan data post test keterampilan berpikir rasional kelas eksperimen di kelas VIII D dengan menggunakan pembelajaran metode discovery Learning dan Buz: group. Sedangkan pengambilan data post test keterampilan berpikir rasional kelas kontrol di kelas VIII C dengan menggunakan pembelajaran metode discovery learning. Berikut hasil uji homogenitas data post test keterampilan berpikir rasional siswa di kelas kontrol dan eksperimen:

Tabel 4. Hasil Uji Homogenitas Data Post Test Keterampilan Berpikir Rasional Kelas Eksperimen dan Kelas Kontrol

\begin{tabular}{crrr}
\hline Levene Statistic & df1 & df2 & Sig. \\
\hline .413 & 1 & 61 & .523 \\
\hline
\end{tabular}

Berdasarkan tabel di atas menunjukan hasil uji hoogenitas dengan menggunakan Levene, data post test keterampilan berpikir rasional dinyatakan homogen atau sama. Karena nilai taraf 
signifikan kelas eksperimen dan kelas kontrol sebesar 0,523 sehingga lebih besar daripada 0,05. Hasil yang diperoleh uji homogenitas Levene dikelas ekperimen dan kontrol yaitu bernilai 0,413 dengan signifikan 0,523 >0,05. Dapat disimpulkan bahwa hasil data post test siswa keterampilan berpikir rasional siswa di kelas eksperimen dan kelas kontrol memiliki data yang homogen atau sama.

Hasil uji analisis data menunjukan bahwa data post test keterampilan berpikir rasional berdistribusi normal dan homogen. Kemudian data post test diuji hipotesis dengan uji $\mathrm{T}$ independent sample menggunakan minitab 16, untuk mengetahui tingkat pengaruh metode discovery learning dengan teknik buzz group terhadap keterampilan berpikir rasional siswa.

Dinyatakan berpengaruh jika hasil uji T-test nilai taraf signifikasinya $<0,05$, terdapat pengaruh penggunaan metode discovery learning dengan teknik buzz group terhadap keterampilan berpikir rasional siswa. Sedangkan apabila taraf signifikasi $>0,05$ maka dinyatakan tidak ada pengaruh penggunaan metode discovery learning dengan teknik buzz group terhadap keterampilan berpikir rasional siswa. Berikut hasil uji $\mathrm{T}$ data post test nilai kelas eksperimen dan kelas kontrol menggunakan minitab 16:

Tabel 5. Hasil Uji T Data Post-Test Kelas Eksperimen

\begin{tabular}{|c|c|c|c|c|}
\hline \multicolumn{5}{|c|}{ Two-sample T for Kelas Eksperimen vs Kelas Kontrol } \\
\hline & $\mathrm{N}$ & Mean & StDev & SE Mean \\
\hline Kelas Eksperimen & 32 & 85.47 & 6.17 & 1.1 \\
\hline Kelas Kontrol & 31 & 70.48 & 7.48 & 1.3 \\
\hline \multicolumn{5}{|c|}{ Difference $=$ mu (Kelas Eksperimen $)-\mathrm{mu}($ Kelas Kontrol $)$} \\
\hline \multicolumn{5}{|c|}{ Estimate for difference: 14.98} \\
\hline \multicolumn{5}{|c|}{ 95\% CI for difference: $(11.53,18.44)$} \\
\hline \multicolumn{5}{|c|}{ T-Test of difference $=0$ (vs not $=$ ): $\mathrm{T}$-Value $=8.68 \mathrm{P}$-Value $=0.000 \mathrm{DF}=61$} \\
\hline
\end{tabular}

Berdasarkan hasil uji $\mathrm{T}$ di atas menunjukan bahwa hasil pengujian nilai rata-rata atau mean kelas eksperimen sebesar 85,47 dengan standart deviasi 6,17 sedangkan kelas kontrol nilai mean sebesar 70,48 dengan standart deviasi 7,48, Sehingga mean kelas eksperimen yang menggunakan metode discovery learning yang disispi teknik burz, group lebih tinggi dari kelas kontrol yang hanya menggunakan metode discovery learning dengan selisih 14,99. Hasil uji independent $T$ test nilai t hitung sebesar 8,68 pada degree of freedom (df) sebesar 61 dan P V alue sebesar 0,000, maka P Value lebih kecil dari 0,05. Sehingga Ho ditolak dan H1 diterima maka terdapat perbedaan kemampuan berpikir rasional pada kelas eksperimen dan kontrol. Dan terdapat pengaruh penggunaan metode discovery learning dengan teknik buгzgroup terhadap keterampilan berpikir rasional siswa

Penelitian ini bertujuan untuk mengetahui pengaruh penggunaan metode discovery learning dengan teknik buzz group terhadap keterampilan berpikir rasional siswa kelas VIII. Penelitian dilaksanakan di SMP Negeri 1 Jenangan Ponorogo kelas VIII D sebagai kelas eksperimen sebanyak 32 siswa dan VIII C sebagai kelas kontrol sebanyak 31 siswa. Metode yang digunakan dalam penelitian adalah metode kuasi eksperimental dengan desain post-test only. Teknik pengumpulan data dengan melakukan observasi kegiatan pembelajaran yang dikelas, tes keterampilan berpikir rasional siswa, dan dokumentasi sebagai bukti pelaksanaan penelitian.

Tahap selanjutnya yaitu analisis data post test keterampilan berpikir rasional siswa uji normalitas dnegan menggunakan uji kolmogrof smirnov dan Saphiro Wilk menggunakan SPSS 16.00, hasil uji kolmogrof smirnov data post test menunjukan bahwa taraf signifikan dari hasil kelas eksperimen sebesar 0,200 > 0,05. Dan pada uji Saphiro Wilk data post test yang diperoleh yaitu sebesar 0,220 > 0,05. Sedangkan data post test uji kolmogrof smirnov taraf signifikan dari hasil kelas kontrol yaitu sebesar 0,067, dan pada uji Saphiro Wilk data post test kelas kontrol yang diperoleh 
yaitu sebesar 0,579. Sehingga data post test keterampilan berpikir rasional siswa dinyatakan berdistribusi normal.

Hasil uji homogenitas dengan menggunakan Levene, data post test keterampilan berpikir rasional dinyatakan homogen atau sama. Karena nilai taraf signifikan kelas eksperimen dan kelas kontrol sebesar 0,523 sehingga lebih besar daripada 0,05. Hasil yang diperoleh uji homogenitas Levene dikelas ekperimen dan kontrol yaitu bernilai 0,413 dengan signifikan 0,523 > 0,05. Dapat disimpulkan bahwa hasil data post test siswa keterampilan berpikir rasional siswa di kelas eksperimen dan kelas kontrol memiliki data yang homogen atau sama.

Penerapan pembelajaran dan penelitian di kelas eksperimen dan kelas kontrol dilakukan selama tiga kali pertemuan. Metode yang diterapkan di kelas kontrol hanya menggunakan discovery learning, sedangkan pada kelas eksperimen menggunkan metode discovery learning dan buzz. grup. Materi yang dibahas yaitu tentang sistem ekskresi manusia. Pada pertemuan pertama kelas kontrol dan eksperimen membahas materi dan berdiskusi tentang sistem ekskresi manusia pada organ ginjal dan kulit, pada pertemuan kedua membahas materi sistem ekskresi manusia pada organ hati dan paru-paru, dan pertemuan terakhir membahas materi gangguan sistem ekskresi dan upaya menjaga kesehatan sistem ekskresi manusia. Dalam menjelaskan materi sistem ekskresi manusia kepada siswa agar materi menjadi rasional, pendidik memberikan apersepsi terlebih dahulu, kemudian menampilkan dan menjelaskan gambar-gambar organ sistem ekskresi manusia. Menjelaskan struktur dan fungsi serta gangguan dan upaya penanganan organ ekskresi. Untuk memperjelas lebih dalam materi siswa melakukan kegiatan diskusi, pemberian tugas LKPD yang disajikan gambar organ ekskresi, siswa disuruh untuk mengamati bagian-bagian struktur, menjelaskan fungsi, dan menyelesaikan beberapa kasus yang berkaitan dengan sistem ekskresi manusia

Bиг: Group merupakan teknik diskusi yang lebih menekankan siswa untuk terlibat aktif dalam pembelajaran, kemandirian siswa dalam mencari informasi, dan mengutarakan pemikirannya. Dalam teknik ini siswa dilatih berpikir kritis dalam menganalisis suatu materi dan dalam menyelesaikan permasalahan. Dengan menggunakan teknik buгz group pembelajaran akan menjadi lebih menarik, siswa menjadi lebih fokus dengan materi yang dibahas, antusias dalam belajar, dan hasil belajar dan keterampilan berpikir rasional meningkat (Suarjana et al., 2014).

Tingkat keterampilan berpikir rasional diukur dari hasil tes penelitian. Keterampilan berpikir rasional adalah kemampuan siswa dalam berpikir, menganalisa, dan penalaran terhadap materi pembelajaran, dalam menyelesaikan permasalahan siswa mencari informasi dari berbagai sumber belajar seperti buku, internet, dan pengalaman, kemudian siswa memahami dan mengolah informasi secara logis dan sesuai konsep. Indikator soal keterampilan berpikir rasional yang meliputi siswa mengingat, menganalisis, mengklasifikasi, menggeneralisasi, dan menyimpulkan (Taufiq \& Nurmaulia, 2015). Pada indikator mengingat siswa memasukan informasi kedalam ingatan dan mengutarakan informasi dalam bentuk penjelasan. Pada indikator menganalisis siswa harus mampu mengamati dan menjabarkan suatu konsep materi yang relevan. Pada indikator mengklasifikasi siswa harus mampu mengelompokkkan atau mengkategorikan obyek atau kasus berdasarkan kriteria konsep yang sesuai. Indikator menggeneralisasi siswa harus mampu mengetahui dan menghubungkan kriteria dari satu atau beberapa konsep yang diamati mempunyai kesamaan dengan konsep-konsep yang lain. Pada indikator menyimpulkan, siswa harus mengetahui poin-poin penting materi, dan dapat menyimpulkan keterpaduan indikator mengingat, menganalisis,mengklasifikasi, dan menggeneralisasi.

Langkah-langkah pembelajaran pada penelitian ini yang menggunakan metode discovery learning dan buzz group, tahapan yang pertama adalah stimulasi, pada kegiatan ini guru memberikan apersesi berupa mengajukan pertanyaan, membaca buku, memberikan gambar, ataupun cerita yang sesuai dengan materi pembelajaran yang akan dibahas. Pemberian apersepsi melatih keterampilan berpikir rasional siswa, menangkap pertanyaan atau cerita yang berkaitan dengan 
materi kemudian informasi tersebut dipahami oleh siswa, dianalisis dan diutarakan hasil pemikirannya. Sehingga siswa mempunyai gambaran awal tentang materi. Siswa akan berpikir rasional dalam indikator mengingat dan menganalisis.

Tahapan yang kedua yaitu langkah Problem Statement (Pernyataan Masalah), pada tahap ini guru menyuruh siswa untuk menganalisis dan mengidentifikasi masalah yang terkait dengan konsep pelajaran. Siswa diberi kesempatan untuk menanya, mengamati, mencari informasi, dan merumuskan masalah. Pada tahap ini teknik diskusi buгz group dilaksanakan, kegiatan diskusi terstruktur setiap kelompok terdiri dari 3-6 orang, terdapat ketua kelompok, notulen, dan anggota kelompok. Dengan adanya ketua kelompok pembagian tugas dan tanggung jawab secara adil kepada teman kelompoknya, sehingga semua anggota ikut aktif dalam kegiatan ini, mencari informasi, menganalisis, bertukar pendapat, berdiskusi, dan mengerjakan tugas. Kegiatan ini dapat melatih dan mengembangkan keterampilan berpikir rasional siswa. Kegiatan ini siswa menerapkan atau melatih indikator mengingat, menganalisis, mengklasifikasi, dan menggeneralisasi.

Tahapan yang ketiga yaitu Data Collection (Pengumpulan Data), pada tahap ini Siswa melakukan pengolahan data dan informasi yang kemudian dianalisis. Pada kegiatan ini melatih keterampilan berpikir logis dan aplikatif. Kegiatan ini siswa menerapkan indikator mengolah informasi dari hasil analisis, dan klasifikasi konsep. Tahap yang keempat yaitu Verifikasi (Pembuktian), pada tahap ini siswa mengecek kebenaran hasil pengolahan data dari diskusi bersama teman-temannya dan dari sumber belajar seperti buku dan internet yang relevan. Pada tahap ini pelaksanaan sesi presentasi dan tanya jawab atau terjadinya diskusi besar antar kelompok, banyak siswa yang aktif dan kritis dalam menanggapi dan bertanya. Tahapan yang terakhir yaitu Generalization (Penarikan Kesimpulan), pada tahap ini merupakan proses menarik kesimpulan dari hasil data dan informasi pengamatan siswa. Sehingga kegiatan ini dapat melatih kemampuan berpikir siswa. Pada tahap ini siswa harus mampu menyimpulkan hasil diskusi kategori indikator menyimpulkan. Siswa menjelaskan secara ringkas point-point penting dari berbagai konsep. Hasil pokok dari analisis suatu masalah atau data-data terpenting dari hasil pengamatan, dan keterpaduan aspek kegiatan berpikir rasional mengingat, menganalisis, menglasifikasi, dan menggeneralisasi.

Pengamatan pada pertemuan pembelajaran yang pertama di kelas eksperimen, keterampilan berpikir rasional siswa pada kegiatan diskusi buzz, group mengerjakan lembar kerja peserta didik (LKPD). Siswa melaksanakan diskusi dengan kondusif, dan pembagian tugas kepada setiap anggota kelompok secara merata. Siswa mencari informasi dari buku dan saling bertukar pendapat dengan teman kelompoknya. Siswa menganalisa sebuah kasus dan mencari serta memahami konsep yang terkait. Kemudian siswa mengolah informasi untuk menyelesaikan masalah. Dan terjadinya kegiatan presentasi dan tanya jawab yang aktif antar kelompok. Namun soal indikator keterampilan berpikir rasional menggeneralisasi siswa belum maksimal, sedangkan indikator lainnya siswa sudah paham.

Pada pertemuan kedua, tingkat keterampilan berpikir rasional siswa meningkat, siswa mulai bisa menyelesaikan soal indikator menggeneralisasi. Siswa mampu mengenali kriteria dari satu atau beberapa kasus yang diamati mempunyai kesamaan dengan konsep-konsep lain yang telah didefinisikan melalui materi yang relevan. Siswa melakukan penyelidikan dengan konsep atau informasi yang diperoleh dan sesuai. Kegiatan diskusi menjadi lebih terstruktur dan kondusif. Pada pertemuan ketiga, siswa sudah bisa memahami dan menerapkan 5 indikator keterampilan berpikir rasional siswa dalam menyelesaikan berbagai kasus atau soal. Hasil diskusi kelompok siswa yang mampu menjawab soal lembar kerja peserta didik (LKPD) dengan tepat. Presentasi kelompok dan tanya jawab antar kelompok yang aktif, siswa menjadi kritis dan sangat antusias. Pada pertemuan ketiga pengambilan tes keterampilan berpikir rasional dengan soal uraian sebanyak 10 butir, dengan setiap indikator terdapat pada 2 soal, indikator meliputi mengingat, menganalisis, mengklasifikasi, menggeneralisasi, dan menyimpulkan. 
Berikut kategori nilai keterampilan berpikir rasional untuk kelas kontrol dan kelas eksperimen :

Tabel 6. Kategori Nilai di Kelas Eksperimen dan Kelas Kontrol

\begin{tabular}{cc}
\hline $\begin{array}{c}\text { Nilai Tes keterampilan } \\
\text { Berpikir Rasional }\end{array}$ & Kategori \\
\hline $85-100$ & Sangat Baik \\
\hline $70-84$ & Baik \\
\hline $54-69$ & Cukup Baik \\
\hline $0-53$ & Kurang \\
\hline
\end{tabular}

Hasil nilai rata-rata post test keterampilan berpikir rasional di kelas eksperimen dan kontrol yaitu:

\section{Tabel 7. Nilai Rata-Rata Post Test Keterampilan Berpikir Rasional di Kelas Eksperimen dan Kontrol}

\begin{tabular}{ccccc}
\hline Kelas & $\begin{array}{c}\text { Nilai } \\
\text { tertinggi }\end{array}$ & $\begin{array}{c}\text { Nilai } \\
\text { Terendah }\end{array}$ & $\begin{array}{c}\text { Rata- } \\
\text { Rata }\end{array}$ & Kategori \\
\hline Kontrol & 85 & 55 & 70,48 & Baik \\
\hline Eksperimen & 95 & 70 & 85,47 & $\begin{array}{c}\text { Sangat } \\
\text { Baik }\end{array}$ \\
\hline
\end{tabular}

Berdasarkan tabel 7 , dapat dijelaskan bahwa nilai rata-rata post test keterampilan berpikir rasional di kelas kontrol sebesar 70,48 dengan kategori baik, sedangkan nilai rata-rata post test keterampilan berpikir rasional di kelas eksperimen sebesar 85,47 sehingga masuk kategori sangat baik. Selisih perbedaan nilai rata-rata kelas eksperimen dan kelas kontrol sebesar 15,99, kelas ekperimen memiliki nilai rata-rata yang lebih tinggi daripada kelas kontrol. Sehingga keterampilan berpikir rasional siswa kelas eksperimen lebih tinggi dari pada keterampilan berpikir rasional siswa kelas kontrol.

Hasil nilai post test pada kelas kontrol rendah karena kegiatan pembelajarannya kurang kondusif, tidak ada ketua kelompok yang bertugas dalam memimpin jalannya diskusi. Sehingga diskusi menjadi kurang efektif, hal ini dibuktikan bahwa sebagian anggota kelompok tidak ikut dalam mencari informasi, tidak ikut membahas suatu permasalahan, maupun dalam mengerjakan soal. Selain itu disebabkan oleh jumlah anggota yang terlalu banyak yaitu setiap kelompok terdiri dari 6-8 siswa.

Pembelajaran di kelas eksperimen yang menggunakan teknik diskusi buzz group, setiap kelompok terdiri dari 4 sampai 5 siswa, setiap siswa mempunyai tugasnya masing-masing. Pada setiap kelompok terdapat ketua, notulen, presentator, anggota kelompok. Buг₹ group dapat meningkatkan kekompakan siswa, dan kemandirian siswa dalam mencari informasi. Diskusi menjadi terstruktur dan efektif, dalam pembagian tugas atau tanggung jawab kepada setiap anggota secara merata, ketua yang memimpin jalannya diskusi dan mengawasi kinerja dari anggota kelompok. Setiap anggota harus mencari informasi, ikut membahas pokok permasalahan, dan berpendapat. Sehingga kegiatan diskusi berjalan dengan lancar atau tidak memakan waktu yang lama, melatih keterampilan berpikir rasional siswa dalam mencari informasi, mengolah, menganalisis, dan menalar pengetahuan. Selain itu siswa menjadi lebih antusias dalam berpendapat atau mengutarakan pikirannya.

Penggunaan metode discovery learning dengan teknik buz: group memberikan implikasi positif untuk kegiatan pembelajaran IPA ataupun mata pelajaran yang lainnya. Karena teknik pembelajaran tersebut sesuai dengan kebutuhan siswa dalam melaksanakan kegiatan pembelajaran dan berpengaruh terhadap hasil keterampilan berpikir rasional siswa. Pada proses pembelejaran terdapat perbedaan keterampilan berpikir rasional yang mendapat perlakuan atau yang 
menerapkan metode discovery learning dengan teknik buгz, goup, dengan proses pembelajaran tidak diberi perlakuan atau hanya menggunakan metode discovery learning.

Dalam pengujian hipotesis peneliti menggunakan Uji $\mathrm{T}$ Independet Sample dengan menggunakan Minitab 16. Hasil uji independent $T$ test nilai t hitung sebesar 8,68 pada degree of freedom (df) sebesar 61 dan P Value sebesar 0,000, maka P Value 0,000<0,05. Sehingga Ho ditolak dan H1 diterima maka terdapat pengaruh penggunaan metode discovery learning dengan teknik buгz group terhadap keterampilan berpikir rasional siswa. Berdasarkan hasil uji $\mathrm{T}$ di atas menyatakan bahwa terdapat pengaruh penggunaan metode discovery learning dengan teknik buz: group terhadap keterampilan berpikir rasional siswa.

Hasil tes keterampilan berpikir rasional kelas eksperimen yang menerapkan metode discovery learning dengan teknik buzz, group lebih tinggi daripada hasil tes pada kelas kontrol. Nilai rata-rata kelas eksperimen sebesar 85,47 sedangkan kelas kontrol sebesar 70,48. Siswa-siswa di kelas eksperimen menguasai soal indikator mengingat, menganali-sis, mengklasifikasi, menggeneralisasi, dan menyimpulkan. Hal tersebut terjadi karena perpaduan metode discovery learning dengan teknik bu₹z group, pada kegiatan yang melatih keterampilan berpikir rasional siswa. Skor pada indikator mengingat dan menganalisis memiliki kategori tinggi, karena sintaks discovery learning stimulation siswa menangkap apersepsi dari guru, kemudian informasi tersebut dipahami, diolah dan mengutarakan hasil pemikirannya, pada sintaks ini siswa mempunyai gambaran awal tentang materi dan tahap analisa awal terhadap materi yang belum dibahas. Pada kegiatan ini guru memberikan apersesi berupa mengajukan pertanyaan, membaca buku, memberikan gambar, ataupun cerita yang sesuai dengan materi pembelajaran yang akan dibahas (Ariani \& Wachidi, 2019; Dewi \& Agustina, 2013; Nurhalimah et al; Widiyati, 2014).

Pada indikator mengingat, menganalisis, mengklasifikasi, dan menggeneralisasi memiliki skor kategori tinggi, karena pada sintaks Problem Statement (pernyataan masalah), dan dimulainya teknik buгz, group kegiatan yang menuntun siswa aktif dan kritis. Siswa menganalisis dan mengidentifikasi masalah yang terkait dengan konsep pelajaran. Pada tahap ini guru menyuruh siswa untuk menganalisis dan mengidentifikasi masalah yang terkait dengan konsep pelajaran. Siswa diberi kesempatan untuk menanya, mengamati, mencari informasi, dan merumuskan masalah (Ariani \& Wachidi, 2019). Sintaks Data Collection (pengumpulan data) proses pengolahan data dan informasi yang kemudian dianalisis. Setelah itu diverifikasi untuk mengecek kebenaran jawaban dengan literatur yang ada, kegiatan ini bisa dilihat dari sintaks problem statement yang mengkondisikan siswa memberikan komentar terkait problem kontekstual. Sedangkan sintaks Generalization (penarikan kesimpulan) skor indikator menyimpulkan memiliki kategori tinggi, proses menarik kesimpulan dari hasil data dan informasi pengamatan siswa. Tahap ini merupakan proses menarik kesimpulan yang dapat dijadikan point-point penting dari berbagai konsep untuk menyelesaikan suatu masalah dan menjelaskan materi yang dibahas, dengan memperhatikan hasil verifikasi (Ariani \& Wachidi, 2019). Hasil pokok dari analisis suatu masalah atau data-data terpenting dari hasil pengamatan, dan keterpaduan aspek kegiatan berpikir rasional mengingat, menganalisis, menglasifikasi, dan menggeneralisasi.

\section{SIMPULAN}

Simpulan berdasarkan hasil penelitian menggunakan observasi dan tes keterampilan berpikir rasional menunjukan bahwa penggunaan metode discovery learning dengan teknik bu₹zgroup siswa menjadi lebih aktif dalam berdiskusi, dapat melatih dan meningkatkan keterampilan berpikir rasional siswa. Hasil pembahasan analisis data uji $\mathrm{T}$ menggunakan minitab 16.0 bahwa nilai $\mathrm{t}$ hitung sebesar 8,68, nilai degree of freedom (df) sebesar 61 dan P Value sebesar 0,000, maka P Value $0,000<0,05$. Sehingga Ho ditolak dan $\mathrm{H}_{1}$ diterima maka terdapat pengaruh penggunaan metode discovery learning dengan teknik buґz group terhadap keterampilan berpikir rasional siswa. Berdasarkan hasil penelitian dan pembahasan tersebut dapat disimpulkan bahwa penggunaan 
metode discovery learning dengan teknik buгz, group berpengaruh terhadap keterampilan berpikir rasional siswa.

\section{REFERENSI}

Al-Tabany, T. I. B. (2017). Mendesain Model Pembelajaran Inovatif, Progresif, dan Konteksual. Prenada Media.

Ariani, P., \& Wachidi, W. (2019). The Implementation of Discovery Learning Model to Improve Student Activities And Learning Achievement Of Pancasila And Civic Education (Ppkn) Of 7th Grade Students in SMPN 8 Rejang Lebong. Jurnal Ilmiah Teknologi Pendidikan, 8(1), $78-87$.

Astuti, R., Sunarno, W., \& Sudarisman, S. (2012). Pembelajaran IPA dengan Pendekatan Keterampilan Proses Sains Menggunakan Metode Eksperimen Bebas Termodifikasi dan Eksperimen Terbimbing Ditinjau dari Sikap Ilmiah dan Motivasi Belajar Siswa. Jurnal Inkuiri, 1(1), 51-59.

Azis, M. S., Tandililing, E., \& Oktavianty, E. (n.d.). Penerapan Metode Buzz Group untuk Meningkatkan Aktivitas dan Hasil Belajar Fisika di SMP. Jurnal Pendidikan Dan Pembelajaran Khatulistiwa, 4(6).

Dewi, C., \& Agustina, C. (2013). Penerapan Strategi SQ3R Untuk Meningkatkan Keterampilan Membaca Pemahaman di Sekolah Dasar. Jurnal Penelitian Pendidikan Guru Sekolah Dasar, 1(2), 1-10.

Ekawati, Y., Sunarno, W., \& Cari, C. (2017). Pembelajaran Fisika Melalui Discovery Learning dengan Metode Eksperimen dan Demonstrasi Ditinjau dari Kemampuan Berpikir Kritis dan Kreativitas Siswa SMK Kelas X pada Materi Sifat Mekanik Bahan. INKUIRI: Jurnal Pendidikan IP A, 6(3), 17-28.

Haeruman, L. D., Rahayu, W., \& Ambarwati, L. (2017). Pengaruh Model Discovery Learning Terhadap Peningkatan Kemampuan Berpikir Kritis Matematis dan Self-Confidence Ditinjau dari Kemampuan Awal Matematis Siswa SMA di Bogor Timur. JPPM Jurnal Penelitian Dan Pembelajaran Matematika), 10(2).

Jamaris, M. (2014). Kesulitan Belajar: Perspektif, Asesmen, dan Penanggulangannya. Ghalia Indonesia.

Kumara, A. (2004). Model Pembelajaran "Active Learning" Mata Pelajaran Sains Tingkat SD Kota Yogyakarta Sebagai Upaya Peningkatan “Life Skills.” Jurnal Psikologi, 31(2), 63-91.

Kusmaryono, H., \& Setiawati, R. (2013). Penerapan Inquiry Based Learning untuk Mengetahui Respon Belajar Siswa pada Materi Konsep dan Pengelolaan Koperasi. Dinamika Pendidikan, $8(2)$.

Lieung, K. W. (2019). Pengaruh Model Discovery Learning terhadap Keterampilan Berpikir Kritis Siswa Sekolah Dasar. Musamus Journal of Primary Education, 1(2), 73-82.

Maghfiroh, L. (2013). Penggunaan Media Flashcard untuk Meningkatkan Hasil Belajar IPS pada Pembelajaran Tematik di Sekolah Dasar. Jurnal Penelitian Pendidikan Guru Sekolah Dasar, 1(2), $1-13$. 
Muchit, S., \& Krisbiyanto. (2010). Cooperative Learning. Rasail Media Group.

Muchlash, I. (2019). Laporan Pelaksanaan Magang.

Mujis, D. (2008). Effective Teaching: Teori dan Aplikasi. Pustaka Pelajar.

Nurhalimah, S., Salim, I., \& Imran, I. (n.d.). Keterampilan Guru Sosiologi Dalam Membuka dan Menutup Pelajaran Untuk Meningkatkan Motivasi Belajar Siswa. Jurnal Pendidikan dan Pembelajaran, 7(5).

Puspitasari, R. (2016). Kontribusi Empirisme Terhadap Pendidikan Ilmu Pengetahuan Sosial. Edueksos: Jumal Pendidikan Sosial \& Ekonomi, 1(1).

Rasyid, M. R. (2008). Optimalisasi Peran Guru dalam Proses Transformasi Pengetahuan dengan Menggunakan Media Pembelajaran. Lentera Pendidikan: Jurnal Ilmu Tarbiyah Dan Keguruan, 11(1), 55-68.

Retnosari, N., Susilo, H., \& Suwono, H. (2016). Pengaruh Model Pembelajaran Inkuiri Terbimbing Berbantuan Multimedia Interaktif terhadap Berpikir Kritis Siswa Kelas XI SMA Negeri di Bojonegoro. Jurnal Pendidikan: Teori, Penelitian, Dan Pengembangan, 1(8), 1529_ 1535.

Rosidah, C. T. (2018). Penerapan Model Problem Based Learning untuk Menumbuh Kembangkan Higher Order Thinking Skill Siswa Sekolah Dasar. INVENTA: Jurnal Pendidikan Guru Sekolah Dasar, 2(1), 62-71.

Samad, L. A. (2011). Meningkatkan Prestasi Belajar Siswa pada Mata Pelajaran IPA Pokok Babasan Pesawat Sederhana dengan Menggunakan Metode Diskusi Kelompok Kecil (Buzz. Gruops) Pada Siswa Kelas 5 MIN Model Sesele Kecamatan Gunung Sari Lombok Barat Tahun Pelajaran 2010/2011 [PhD Thesis]. UIN Mataram.

Suarjana, G., Garminah, N. N., Hum, M., \& Mahadewi, L. P. P. (2014). Pengaruh Teknik BUZZ GROUP terhadap Aktivitas dan Hasil Belajar IPS Siswa SD. MIMBAR PGSD Undiksha, 2(1).

Sugiyono. (2014). Metode Penelitian Pendidikan Kuantitatif, Kualitatif, dan R\&̊D. Alfabeta.

Suryati, S. (2014). The Effect of LC Learning Model Combined with Flow Chart to the Quality Process, Results Learning and Metacognitive Ability of Students. Jurnal Pendidikan Sains, 1(1), 1-13.

Taufiq, M., \& Nurmaulia, N. (2015). Pengaruh Penerapan Pembelajaran Kooperatif Tipe Student Team Achievement Division terhadap Keterampilan Berpikir Rasional Siswa Kelas VIII SMP Negeri 1 Dewantara Pada Materi Pesawat Sederhana. Jurnal Pendidikan Almuslim, 1.

Widiyati, E. (2014). Peningkatan Minat dan Kemampuan Membaca Permulaan Melalui Media Buku Cerita Binatang dan Permainan Bahasa Siswa Kelas II SD Plus Al-Anwar Pacul Gowang Jombang. Jurnal Pendidikan Humaniora (JPH), 1(4), 405-413.

Yupita, I. A. (2013). Penerapan Model Pembelajaran Discovery untuk Meningkatkan Hasil Belajar IPS di Sekolah Dasar. Jurnal Penelitian Pendidikan Guru Sekolah Dasar, 1(2), 1-10. 